JKKP : Jurnal Kesejahteraan Keluarga dan Pendidikan

http://doi.org/10.21009/JKKP

DOI: doi.org/10.21009/JKKP.052.01

E-ISSN : 2597-4521

\title{
HUBUNGAN POLA ASUH OTORITER TERHADAP PERILAKU PERUNDUNGAN PADA REMAJA
}

\author{
Fildzah Rudyah Putri', a), dan Fivi Nurwianti', b) \\ Email : a) fildzahrudyah@gmail.com, $^{\text {b) }}$ fivinurwianti2016@gmail.com \\ 1,2)Fakultas Psikologi, Universitas Indonesia, Jl. Margonda Raya, Kota Depok, (021) 7863520
}

\begin{abstract}
Abstrak
Perilaku perundungan atau bullying semakin marak terjadi dan hal tersebut saat ini sudah menjadi perhatian, mengingat dampaknya yang sangat fatal. Pola asuh yang diterapkan oleh orang tua diketahui menjadi faktor kuat dalam membentuk perilaku perundungan tersebut. Dari ketiga jenis pola asuh orang tua yang dikemukakan Baumrind, pola asuh otoriter diketahui menjadi faktor yang paling kuat dalam membentuk perilaku tersebut. Oleh sebab itu, dalam penelitian ini, pola asuh yang akan diuji hanya difokuskan pada pola asuh otoriter yang diteliti untuk melihat seberapa besar perannya dalam membentuk perilaku perundungan. Penelitian perundungan ini nantinya akan dilakukan pada kelompok usia remaja, yaitu pada masa transisi perkembangan individu dari masa kanak-kanak menuju masa dewasa, dimana pada masa ini terjadi perkembangan dan perubahan yang sangat pesat dari sisi fisik, psikologis, dan sosial. Sampel yang digunakan terdiri dari 272 orang (59,6\% perempuan, dan 40,4\% laki-laki) dengan rentang usia 16 hingga 19 tahun. Dengan menggunakan teknik analisis regresi, diketahui bahwa pola asuh otoriter secara signifikan terbukti berhubungan dengan perilaku perundungan. Sebesar $11 \%$ dari perilaku perundungan diketahui dibentuk oleh pola asuh otoriter.
\end{abstract}

Kata Kunci: perundungan, pola asuh otoriter, remaja

\section{The Effect of Authoritarian Parenting Toward Bullying Behaviour Among Adolescence}

\begin{abstract}
Bullying behaviour has been increasing in Indonesia. Parenting styles are considered as one of the strongest factor in shaping the behaviour. From the three types of parenting style proposed by Baumrind, authoritarian parenting shown to be the most powerful factor in shaping bullying behaviour. So, in this study, the parenting that will be tested only focuses on the authoritarian parenting. The aim of this study is to see how big the role of authoritarian parenting in shaping bullying behaviour. This bullying research will be conducted in adolescent, it was the transition period of individual development from childhood to adulthood. Participants in this study were 272 people $(59,6 \%$ female and $40,4 \%$ male). Participants were adolescents with age ranged from 16 to 19 years old. Using regression analysis techniques, it is known that authoritarian parenting has significantly been associated with bullying behaviour. As much as $11 \%$ of the bullying behaviour is known to be shaped by authoritarian parenting.
\end{abstract}




\section{PENDAHULUAN}

Perundungan atau bullying merupakan salah satu tindakan penindasan yang terjadi secara berulang, dan dilakukan dengan sengaja oleh seseorang atau beberapa orang dengan niat untuk menimbulkan penderitaan ataupun perasaan tidak menyenangkan terhadap orang lain yang memiliki kekuatan lebih lemah (Olweus, 2004). Menurut United Nations International Children's Emergency Fund (UNICEF), sebanyak 50\% anak-anak mengalami perundungan di sekolah (Kompas, 2016). Hal tersebut sejalan dengan laporan yang diterima oleh Kementerian Sosial (Kemensos) pada tahun 2015 yang mengatakan bahwa sebanyak $84 \%$ siswa di Indonesia mengaku mengalami kekerasan di sekolah (Kompas, 2016). Sementara, dari data yang diperoleh hingga bulan Juli 2017, diketahui bahwa selama tahun 2017 terdapat 117 kasus perundungan (cnnindonesia, 2017).

Saat ini berbagai lembaga sedang berusaha mencari langkah yang tepat untuk meminimalisir terjadinya perilaku perundungan, seperti membentuk satuan tugas (satgas) anti-perundungan di sekolah (Liputan 6, 2017). Hal ini dilkukan mengingat angka perundungan yang dinilai cukup mengkhawatirkan. Selain itu, perilaku perundungan juga perlu mendapatkan perhatian dan tindakan khusus untuk menghindari dampak negatif yang akan terjadi baik kepada korban, maupun pelaku. Korban perundungan dapat mengalami simtom psikosomatis (Gini \& Pozzoli, 2013), gangguan tidur (Van Geel et al., 2016) dan bunuh diri (Holt et al., 2015). Sedangkan dampak yang akan dialami oleh pelaku perundungan dapat berupa kecenderungan mengkonsumsi minuman beralkohol dan rokok dengan jumlah yang lebih banyak dibandingkan individu yang tidak melakukan perundungan (Nansel et al., 2001).

Menurut Sullivan (2001), pelaku perundungan memiliki empati yang rendah, tidak peduli, agresif, impulsif, dan memiliki kebutuhan akan dominasi yang tinggi. Pelaku dari perundungan juga cenderung bersikap positif terhadap kekerasan, memiliki kemampuan bekerjasama yang rendah, dan memiliki kesulitan dalam memproses informasi sosial. Fisik dari seorang pelaku perundungan juga cenderung lebih kuat dan besar. Terdapat beberapa bentuk perundungan, seperti fisik, verbal dan relasional (Olweus, 2004). Perundungan verbal berhubungan dengan kata-kata yang dikeluarkan secara verbal, seperti tindakan memaki, menghina, memfitnah dan memberikan julukan yang tidak menyenangkan. Sementara perundungan dalam bentuk fisik dilakukan secara langsung dan di dalam prosesnya terdapat kontak fisik antara pelaku dan korban, seperti memukul, menampar, mendorong, menendang dan berbagai tindakan kontak fisik lainnya. Perundungan dalam bentuk relasional merupakan semua tindakan yang bersifat merusak hubungan dengan orang lain, seperti mengucilkan seseorang.

Menurut Olweus (dalam Cook dkk, 2010), perundungan merupakan salah satu dari bentuk agresi, dengan ciri menyalahgunakan kekuasaan secara berulang dan sistematis. Ketika ditinjau dari perspektif teori belajar, lingkungan eksternal berkontribusi dalam membentuk agresi (Bandura, 1973, 1986). Sedangkan, lingkungan sosial pertama dalam hidup seseorang adalah keluarga, sehingga keluarga memiliki peran penting dalam perkembangan remaja (Santrock, 2007). Di dalam sebuah keluarga, orang tua memengang peranan penting, sehingga perilaku seorang anak di kemudian hari sangat dipengaruhi oleh pola asuh dan bentuk hubungan antara orang tua dengan anaknya.

Pola pengasuhan orang tua merupakan kumpulan sikap, perilaku orang tua, dan pola interaksi antara anak dan orang tua yang berperan dalam membentuk kepribadian anak (Darling dan Sternberg, 1993). Dacey dan Fiore (2000) mengatakan bahwa pola asuh orang tua merupakan seluruh perilaku yang digunakan oleh orang tua dalam hubungannya dengan keluarga mereka, seperti menetapkan disiplin terhadap anak-anaknya. Oleh sebab itu, pola asuh yang tepat dalam mendidik anak sangat dibutuhkan, karena buruknya perhatian dan pengawasan orang tua, penerapan aturan yang tidak menentu, orang tua yang tidak harmonis, dan penolakan dari orang tua mampu menimbulkan masalah perilaku pada anak (Stouthamer-Loeber, 1986; Loeber, \& Hay, 1997).

Terdapat tiga jenis pola asuh yang digunakan oleh orang tua, yaitu otoriter, permisif dan otoritatif (Baumrind, 1966). Namun di antara ketiga jenis pola asuh tersebut, diketahui bahwa individu yang melakukan perundungan dibesarkan oleh orang tua yang menerapkan pola asuh otoriter, kasar dan menghukum (Farrington, 1994; Espelage et al., 2000; Knafo, 2003; Swearer \& Hymel, 2015). 
Orang tua yang menerapkan pola asuh otoriter merupakan orang tua yang dalam proses pendisiplinannya menggunakan hukuman (Baumrind, 1966). Selain itu, kepatuhan, kesesuaian, kontrol orang tua, penghormatan terhadap pihak otoritas dan pemeliharaan ketertiban juga menjadi hal yang penting untuk orang tua yang menerapkan pola asuh otoriter (Bornstein \& Zlotnik, 2008). Sementara menurut Buri (1991), orang tua yang otoriter cenderung akan sangat memberikan perintah dan arahan kepada anak-anak mereka. Orang tua ini juga akan menghargai ketaatan dalam menjalankan otoritas mereka terhadap anak-anak, sehingga mereka tidak mengizinkan anak membantah atau memberikan pertanyaan saat diberikan perintah atau arahan.

Untuk lingkungan Asia, saat ini Indonesia diketahui menempati posisi pertama dalam kasus perundungan yang paling banyak terjadi (Sindonews, 2017). Fenomena tersebut diduga terjadi karena banyak orang tua di Indonesia yang menerapkan pola asuh otoriter. Mayoritas keluarga di Indonesia dikepalai oleh seorang ayah yang otoriter, dan dalam banyak kasus bertindak sebagai sosok otoritas yang harus dihormati (Mulder, 1999). Sejalan dengan itu, lebih dari setengah ibu yang bekerja secara profesional di Indonesia juga diketahui menerapkan pola asuh otoriter pada anak mereka (Joewono, 2002).

Umumnya kasus perundungan terjadi pada masa remaja, sehingga penelitian ini akan dilakukan pada individu yang berada pada kelompok usia remaja, yaitu masa dimana seseorang mengalami transisi dari masa kanak-kanak menuju dewasa. Pada masa remaja ini, individu akan mengalami perkembangan dan perubahan yang pesat, baik dari sisi fisik, psikologis dan sosial (Potter \& Perry, 2005). Menurut Papalia dan Olds (2009), masa remaja umumnya dimulai pada usia 12-13 tahun dan berakhir pada usia akhir belasan atau awal dua puluhan tahun. Pada masa remaja ini, meskipun seseorang cenderung lebih banyak menghabiskan waktu bersama rekannya, nilai-nilai dasar remaja akan tetap lebih dekat dengan nilai-nilai orang tua mereka (Offer \& Church, dalam Papalia, Olds, \& Feldman, 2009). Berdasarkan berbagai teori dan hasil penelitian tersebut, maka perlu dilakukan penelitian untuk mengetahui pengaruh pola asuh otoriter terhadap perilaku perundungan.

\section{METODOLOGI PENELITIAN}

Sampel yang digunakan dalam penelitian ini merupakan remaja dengan rentang usia 16-19 tahun. Partisipan dalam penelitian ini adalah siswa dan siswi kelas dua dan tiga dari 5 Sekolah Menengah Atas (SMA) yang berada di wilayah Jakarta. Awalnya subyek dalam penelitian ini berjumlah 302 orang, namun 30 orang di antaranya dikeluarkan dari penelitian karena tidak memenuhi syarat dalam melakukan perundungan dan tidak mengisi instrument penelitian secara lengkap. Sebelum menjadi responden dalam penelitian ini, siswa akan diberikan informed consent terlebih dahulu, dan mereka diminta untuk menandatangani lembar persetujuan menjadi responden dan publikasi. Mereka juga mendapatkan lembaran parental consent yang berisi penjelasan mengenai penelitian dan lembar persetujuan yang harus ditandatangani orang tua sebagai wujud pemberian izin agar anaknya dapat menjadi responden dalam penelitian ini.

Penelitian ini menggunakan strategi penelitian cross-sectional study, yaitu pengukuran semua variabel dilakukan dalam satu kali pengambilan data. Ditinjau dari proses pengambilan datanya, penelitian ini menggunakan metode survei, di mana penelitian survei hanya dilakukan atas sampel dalam populasi. Setelah melalui proses analisis, hasil yang diperoleh akan diinterpretasi untuk memperoleh kesimpulan dari penelitian. Data dalam penelitian ini diperoleh melalui penggunaan instrumen yang berbentuk kuesioner atau angket.

Perilaku perundungan remaja diukur dengan menggunakan Bullying Questionnaire yang dikembangkan oleh Duffy (2004). Alat ukur perundungan tersebut sudah dimodifikasi dan diadaptasi ke dalam bahasa dan budaya Indonesia oleh Murti (2013). Alat ukur yang terdiri dari 27 aitem ini berbentuk skala likert dengan 4 pilihan jawaban (tidak pernah $=1$; jarang $=2$; kadang-kadang $=3$; sering $=4$ ).

Untuk menguji pola asuh otoriter, Parental Authority Questionnaire (PAQ) yang dikembangkan oleh Buri (1991) digunakan dalam penelitian ini. Alat ukur yang terdiri dari 30 aitem ini didesain untuk 
mengukur perspektif anak terhadap pola asuh yang dilakukan oleh orang tua mereka. Alat ukur ini juga berbentuk skala likert dengan 5 pilihan jawaban yang memiliki rentang 'sangat tidak setuju' hingga 'sangat setuju'. Berdasarkan kebutuhan penelitian, maka hanya aitem yang mengindikasikan pola asuh otoriter saja yang digunakan, yaitu terdiri dari 10 aitem.

Proses analisis data dilakukan dengan menggunakan aplikasi SPSS 21 for Windows. Sementara teknik analisis data yang digunakan adalah regression, yaitu sebuah teknik analisis yang digunakan untuk memprediksi nilai variabel dependen (DV) dari satu variabel prediktor atau IV (Field, 2009).

\section{HASIL DAN PEMBAHASAN}

Partisipan dalam penelitian ini adalah siswa dan siswa Sekolah Menengah Atas (SMA) sederajat. Kelima sekolah yang menjadi lokasi pengambilan data memiliki akreditasi A. Jumlah partisipan yang terlibat dalam penelitian ini sebanyak 272 orang siswa. Berikut adalah gambaran umum partisipan yang mengikuti penelitian berdasarkan data kontrol yang diberikan pada kuesioner.

Tabel 1. Sebaran Data Demografis

\begin{tabular}{ccccc}
\hline Kategori & $\mathbf{N}$ & Keterangan & Frekuensi & Persentase (\%) \\
\hline \multirow{2}{*}{ Jenis Kelamin } & \multirow{2}{*}{272} & Laki-laki & 110 & 40,4 \\
& & Perempuan & 162 & 59,6 \\
\hline \multirow{3}{*}{ Usia } & \multirow{2}{*}{272} & 16 & 70 & 25,7 \\
& & 17 & 166 & 61,0 \\
& & 19 & 28 & 10,5 \\
& & 8 & 2,9 \\
\hline \multirow{5}{*}{ Sekolah } & \multirow{2}{*}{272} & SMK Swasta A & 78 & 28,7 \\
& & SMA Negeri B & 43 & 15,8 \\
& & SMA Swasta C & 77 & 28,3 \\
& & SMA Negeri D & 19 & 7,0 \\
& & SMA Negeri E & 55 & 20,2 \\
\hline
\end{tabular}

Berdasarkan tabel di atas, diketahui bahwa siswa yang paling banyak menjadi partisipan dalam penelitian ini berjenis kelamin perempuan dengan jumlah 162 orang siswi. Sebanyak 78 orang dari keseluruhan partisipan berasal dari SMK Swasta A, sekolah kejuruan akuntansi di Jakarta Selatan. Sebagian besar dari partisipan tersebut berusia 17 tahun. Sehingga dapat disimpulkan bahwa responden penelitian ini didominasi oleh perempuan, berusia 17 tahun dan bersekolah di SMK Swasta A.

Dalam penelitian ini terdapat dua variabel utama, yaitu perundungan, dan pola asuh otoriter. Setelah melalui proses pengambilan data, kedua variabel tersebut dianalisis untuk mengetahui nilai minimum, maksimum dan rata-rata dari setiap variabel. Berikut adalah gambaran dari ketiga variabel penelitian tersebut.

Tabel 2. Data Deskriptif Penelitian

\begin{tabular}{lccccc}
\hline \multicolumn{1}{c}{ Variabel } & N & Minimum & Maksimum & Mean & SD \\
\hline Perundungan & 272 & 35 & 75 & 50,43 & 8,67 \\
Pola Asuh Otoriter & 272 & 9 & 38 & 21,82 & 6,19 \\
\hline
\end{tabular}

Berdasarkan tabel di atas, maka diketahui bahwa skor perundungan pada kelompok penelitian ini berada pada rentang 35 hingga 75 dengan nilai rata-rata 50,43. Sehingga dapat dikatakan bahwa individu dengan skor di atas 50,43, merupakan individu yang sering melakukan perundungan. Dari tabel tersebut juga diketahui bahwa tingkat perundungan yang dilakukan oleh partisipan dalam penelitian ini beragam. Hal ini dapat dilihat dari skor SD yang diperoleh variabel 
perundungan yang lebih besar dibandingkan skor SD pola asuh otoriter. Besarnya skor SD yang diperoleh dapat dimaknai sebagai semakin jauhnya titik individu dari nilai rata-rata kelompok yang diperoleh.

Dari penelitian-penelitian terdahulu, diketahui bahwa laki-laki lebih sering melakukan perundungan. Sehingga, proses uji beda untuk mengetahui perilaku perundungan berdasarkan jenis kelaminnya dilakukan dalam penelitian ini. Ketika dilakukan pengujian secara lebih mendalam terkait jenis kelamin, diketahui bahwa perilaku perundungan berbeda pada setiap jenis kelamin. Hal tersebut terbukti dari nilai signifikansi 2-tailed sebesar $0,00(t=4,35)$.

Tabel 3. Statistik Kelompok Perilaku Perundungan

\begin{tabular}{ccccc}
\hline Jenis Kelamin & N & Mean & SD & Std. Error Mean \\
\hline Laki-laki & 110 & 53,14 & 8,79 & 0,84 \\
\hline Perempuan & 162 & 48,56 & 8,11 & 0,64 \\
\hline
\end{tabular}

Setelah terbukti jika perundungan berbeda secara signifikan jika ditinjau berdasarkan jenis kelamin, selanjutnya dilihat jenis kelamin mana yang paling sering melakukan perundungan. Berdasarkan tabel tersebut, diketahui bahwa laki-laki $(M=53,14)$ lebih sering melakukan perundungan jika dibandingkan perempuan.

Tabel 4. Hasil Uji Regresi Antara Pola Asuh Otoriter Terhadap Perundungan

\begin{tabular}{ccccc}
\hline Model & $\mathbf{R}$ & $\mathbf{R}^{\mathbf{2}}$ & Adjusted $\mathbf{R}^{\mathbf{2}}$ & Estimasi Standar Eror \\
\hline 1 & 0,34 & 0,11 & 0,11 & 8,18 \\
\hline
\end{tabular}

Berdasarkan tabel di atas, diketahui bahwa pola asuh otoriter secara signifikan berpengaruh terhadap perilaku perundungan dengan kontribusi adjusted $R^{2}$ sebesar 0,11 . Sehingga dapat dikatakan bahwa pola asuh otoriter memiliki peran sebesar $11 \%$ dalam membentuk perilaku perundungan, sedangkan $89 \%$ lainnya dibentuk oleh variabel lain.

Tabel 5. Koefisien Pola Asuh Otoriter Terhadap Perundungan

\begin{tabular}{|c|c|c|c|c|c|c|c|}
\hline \multirow{2}{*}{ Model } & \multicolumn{2}{|c|}{$\begin{array}{l}\text { Unstandardized } \\
\text { Coefficients }\end{array}$} & \multirow{2}{*}{$\begin{array}{c}\begin{array}{c}\text { Standardized } \\
\text { Coefficients }\end{array} \\
\text { Beta }\end{array}$} & \multirow{2}{*}{$t$} & \multirow{2}{*}{ Sig. } & \multicolumn{2}{|c|}{ Collinearity } \\
\hline & B & $\begin{array}{l}\text { Std. } \\
\text { Error }\end{array}$ & & & & Tolerance & VIF \\
\hline (Constant) & 39,99 & 1,84 & & 21,77 & 0,00 & & \\
\hline Pola Asuh Otoriter & 0,48 & 0,08 & 0,34 & 5,89 & 0,00 & 1,000 & 1,000 \\
\hline
\end{tabular}

Berdasarkan tabel tersebut, diketahui pola asuh otoriter terhadap perundungan memiliki nilai sig. 0,00 atau $p<0,05$, artinya secara signifikan terdapat perubahan perundungan dengan adanya perubahan pola asuh otoriter. Persamaan regresi dari tabel 5 tersebut adalah $\hat{Y}=39.99+0.48$ (Pola Asuh), artinya setiap kenaikan satu unit skor pola asuh otoriter, maka akan meningkatkan 0,48 skor perundungan. Bermakna juga semakin tinggi skor pola asuh otoriter seseorang, maka perilaku perundungan yang ia lakukan juga akan semakin tinggi.

Hasil penelitian yang diperoleh sejalan dengan Fortuna dan Taganing (2008) yang mengatakan bahwa pola asuh otoriter memiliki hubungan dengan perilaku agresif pada remaja. Kemarahan dan kekesalan pada anak mungkin akan timbul seiring dengan hukuman yang diberikan orang tua dengan pola asuh otoriter. Ketika anak yang menyimpan kemarahan ini tidak berani mengungkapkan perasaannya, ia akan cenderung mencari pelampiasan kepada orang lain dalam bentuk perilaku perundungan.

Keputusan untuk terlibat dalam perilaku perundungan tentunya melalui sebuah proses berpikir di dalam diri yang dipengaruhi oleh beberapa faktor, salah satunya pola asuh orang tua otoriter. Hal tersebut sejalan dengan teori yang diungkapkan para Behaviorist, yaitu bayi terlahir kosong, dan orang tua bertanggung jawab untuk mengarahkan dan mengajarkan anak sesuai Jurnal Kesejahteraan Keluarga dan Pendidikan [JKKP] Vol.05 No.02 doi.org/10.21009/JKKP.052.01 
keinginan orang tua (Keshavarz \& Baharudin, 2009). Oleh sebab itu, nilai-nilai yang ditanamkan dalam proses pengasuhan sangat mempengaruhi perilaku dan sikap seorang remaja. Berdasarkan berbagai penelitian, diketahui bahwa orang tua yang mengadaptasi pola asuh otoriter, memberikan tingkat kehangatan yang rendah dan menghukum anak dengan keras dapat menjadi pemicu perilaku perundungan pada seseorang.

Ketika anak masih kecil, lingkungan pertama yang akan membentuk pola pikir dan perilakunya adalah orang tua. Sehingga saat orang tua memperlakukan anak secara keras dan penuh intimidasi, anak akan cenderung mempelajari serta meniru perilaku tersebut. Anak dengan pola asuh otoriter juga mungkin tidak memperoleh pendidikan mengenai cara berinteraksi yang positif dan tepat dengan orang lain, karena pola interaksi yang ia peroleh hanya yang penuh intimidasi dari orang tua mereka. Dengan berbagai alasan tersebut, maka anak dengan pola asuh otoriter sangat mungkin untuk melakukan perilaku perundungan terhadap rekannya.

\section{KESIMPULAN}

Pola asuh otoriter terbukti mempengaruhi perilaku perundungan secara signifikan pada remaja di sekolah SLTA wilayah Jakarta. Pola asuh otoriter memiliki peran sebesar $11 \%$ dalam membentuk perilaku perundungan. Sedangkan $89 \%$ lainnya dibentuk oleh variabel lain. Pola asuh otoriter terhadap perundungan memiliki nilai sig. 0,00 atau $p<0,05$, artinya secara signifikan terdapat perubahan perundungan dengan adanya perubahan pola asuh otoriter. Persamaan regresi dari tabel 5 tersebut adalah $\hat{y}=39.99+0.48$ (pola asuh), artinya setiap kenaikan satu unit skor pola asuh otoriter, maka akan meningkatkan 0,48 skor perundungan.

Berdasarkan hasil penelitian yang diperoleh, maka diketahui bahwa penerapan pola asuh memiliki peran penting dalam kehidupan seorang anak. Perilaku dan sikap yang ada pada diri seseorang merupakan hasil dari internalisasi nilai-nilai yang ditanamkan oleh orang tua. Dengan demikian, hasil penelitian ini diharapkan dapat menjadi masukan kepada orang tua untuk mengasuh anak mereka dengan pola pengasuhan yang tepat karena akan memberikan dampak langsung pada anak.

Dari hasil penelitian yang diperoleh, diharapkan dapat bermanfaat bagi pihak terkait, seperti Komite Nasional Perlindungan Anak, Kementerian Pemberdayaan Perempuan dan Perlindungan Anak, serta Kementerian Sosial untuk melakukan promosi terkait perundungan. Diharapkan promosi tersebut dapat memberikan pengetahuan kepada orang awam mengenai perundungan, dampak perundungan, serta lebih khusus memberikan pengetahuan kepada orang tua mengenai cara pengasuhan yang tepat untuk mendidik anak.

\section{DAFTAR PUSTAKA}

Bandura, A. 1973. Aggression: A Social Learning Analysis. Stanford Law Review, 26(1), 239. http://dx.doi.org/10.2307/1227918

Baumrind, D. 1966. Effects of authoritative control on child behavior. Child Development, 37, 887-907.

Bornstein, M. H., \& Zlotnik, D. 2008. Encyclopedia of Infant and Early Childhood Development. Elsevier Inc.

Buri, J. R. 1991. Parental Authority Questionnaire. Journal of Personality Assessment, 57, 110-119.

Cook, C. R., Williams, K. R., Guerra, N. G., Kim, T. E., \& Sadek, S. 2010. Predictors of Bullying and Victimization in Childhood and Adolescence: A Meta-analytic Investigation. School Psychology Quarterly, 65-83. : http://dx.doi.org/10.1037/a0020149.supp.

Duffy, A. L. 2004. Bullying in school: A social identity perspective. (Disertasi doktor). Australia: Griffith University. 
Espelage, D., Bosworth, K., \& Simon, T. 2000. Examining the Social Context of Bullying Behaviors in Early Adolescence. Journal Of Counseling \& Development, 78(3), 326-333. http://dx.doi.org/10.1002/j.1556-6676.2000.tb01914.x

Farrington, D. 1994. Early developmental prevention of juvenile delinquency. RSA Journal, 22-34. http://www.jstor.org/stable/41376602

Fortuna, F., Taganing, N. M. 2008. Hubungan pola asuh otoriter dengan perilaku agresif pada remaja. Skripsi. Universitas Gunadarma.

Gini, G., \& Pozzoli, T. 2013. Bullied Children and Psychosomatic Problems: A Metaanalysis. PEDIATRICS, 132(4), 720-729. http://dx.doi.org/10.1542/peds.2013-0614

Hartik, A. 2016. 84 persen siswa Indonesia alami kekerasan di sekolah. Kompas. Diakses dari http://regional.kompas.com/read/2016/11/29/16005801/84.persen.siswa.indonesia.alami.kekerasan.di. sekolah pada tanggal 16 Oktober 2017 pada pukul 22.52.

Holt, M. K., Vivolo-Kantor, A. M., Polanin, J. R., Holland, K. M., DeGue, S., Matjasko, K. L., Reid, G. 2015. Bullying and suicidal ideation and behaviours: A meta-analysis. Pediatrics, 135, 496-509.

Joewono, E. B. 2002. Parenting pada ibu yang bekerja sebagai professional dengan anak usia $8-10$ tahun. Unpublished master thesis, Faculty of Psychology, University of Indonesia.

Keshavarz, S., \& Baharudin, R. 2009. Parenting style in a collectivist culture of Malaysia. European Journal of Social Sciences.

Knafo, A. 2003. Authoritarians, the Next Generation: Values and Bullying Among Adolescent Children of Authoritarian Fathers. Analyses Of Social Issues And Public Policy, 3(1), 199-204. http://dx.doi.org/10.1111/j.1530-2415.2003.00026.x

Mulder, N. 1999. Agama, Hidup Sehari-Hari dan Perubahan Budaya. PT Gramedia Pustaka Utama, Jakarta.

Murti, R. A. 2013. Hubungan antara family functioning dan keterlibatan dalam perilaku bullying pada siswa SMA di Jakarta dan Depok. Fakultas Psikologi Universitas Indonesia. Skripsi.

Muthmainah, D. A. 2017. Semakin banyak yang melaporkan kasus bullying. CNN Indonesia. Diakses dari https://www.cnnindonesia.com/gaya-hidup/20170722163858-277-229641/semakin-banyak-yangmelaporkan-kasus-bullying/ pada tanggal 10 Oktober 2017 pada pukul 00.30.

Nansel, T. R., Overpeck, M., Pilla, R. S., Ruan, W. J., Simons-Morton, B., \& Scheidt, P. 2001. Bullying behaviours among US youth: Prevalence and association with psychosocial adjustment. JAMA, 285, 2094-2100.

Nugroho, F. E. 2016. Kak Seto minta satgas anti-bullying di sekolah segera dibentuk. Liputan 6. Diakses dari http://news.liputan6.com/read/3039682/kak-seto-minta-satgas-anti-bullying-di-sekolahsegera-dibentuk pada tanggal 16 Oktober 2017 pada pukul 23.15 .

Olweus, D. 2004. Bullying in schools: how successful can interventions be?. Cambridge University Press, New York.

Papalia, D. E., Old s, S. W., \& Feldman, R. D. 2009. Human Development Perkembangan Manusia. Salemba Humanika, Jakarta.

Potter, P.A.,\& Perry, A.G. 2005. Buku Ajar Fundamental Keperawatan: Konsep, Proses, dan Praktik(Volume 2) (Edisi 4). Jakarta: EGC

Santrock, J.W. 2007. Psikologi Perkembangan. Edisi 11 Jilid 1. Erlangga, Jakarta.

Sullivan, K. 2011. The anti-bullying handbook. London: SAGE.

Swearer, S., \& Hymel, S. 2015. Bullying and Discrimination in Schools: Exploring Variations Across Student Subgroups. School Psychology Review, 44(4), 504-509. http://dx.doi.org/10.17105/15-0133.1

Van Geel, M., Goemans, A., \& Vedder, P. H. 2016. The relation between peer victimization and sleeping problems: A meta-analysis. Sleep Medicine Reviews, 27, 89-95.

Jurnal Kesejahteraan Keluarga dan Pendidikan [JKKP] Vol.05 No.02

doi.org/10.21009/JKKP.052.01 
Weekly, S. 2017. Indonesia tempati posisi perundungan di Asean. Sindonews. Diakses dari https://nasional.sindonews.com/read/1223442/15/indonesia-tempati-posisi-tertinggi-perundungan-diasean-1500880739) pada tanggal 22 Januari 2018 pada pukul 15.03. 